Technological University Dublin

DÜBLIN

ARROW@TU Dublin

2018

\title{
Lessons from the global financial crisis-the case of Mainland China and Hong Kong
}

Lucia Morales

Technological University Dublin, lucia.morales@tudublin.ie

Bernadette Andreosso-O'Callaghan

University of Limerick

Follow this and additional works at: https://arrow.tudublin.ie/buschacart

Part of the Accounting Commons

\section{Recommended Citation}

Lucía Morales \& Bernadette Andreosso-O'Callaghan (2018) Lessons from the global financial crisis - the case of Mainland China and Hong Kong, Journal of Chinese Economic and Business Studies, 16:4, 375-392, DOI: 10.1080/14765284.2018.1470416

This Article is brought to you for free and open access by the School of Accounting and Finance at ARROW@TU Dublin. It has been accepted for inclusion in Articles by an authorized administrator of ARROW@TU Dublin. For more information, please contact arrow.admin@tudublin.ie, aisling.coyne@tudublin.ie, gerard.connolly@tudublin.ie.

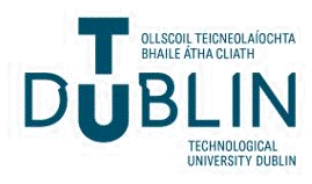




\section{Lessons from the global financial crisis - the case of Mainland China and Hong Kong}

\section{Lucía Morales \& Bernadette Andreosso-O’Callaghan}

To cite this article: Lucía Morales \& Bernadette Andreosso-O'Callaghan (2018) Lessons from the global financial crisis - the case of Mainland China and Hong Kong, Journal of Chinese Economic and Business Studies, 16:4, 375-392, DOI: 10.1080/14765284.2018.1470416

To link to this article: https://doi.org/10.1080/14765284.2018.1470416

\section{Published online: 28 May 2018.}

Submit your article to this journal $\sqsubset$

山ll Article views: 693

Q View related articles $\widetilde{ }$

View Crossmark data \lceil 


\title{
Lessons from the global financial crisis - the case of Mainland China and Hong Kong
}

\author{
Lucía Morales $^{\mathrm{a}}$ (D) and Bernadette Andreosso-O'Callaghan ${ }^{\mathrm{b}, \mathrm{c}}$ \\ aDeparment of Accounting and Finance, College of Business, Dublin Institute of Technology, Dublin, Republic \\ of Ireland; 'bean Monnet Chair of Economics, Kemmy Business School, University of Limerick, Limerick, \\ Republic of Ireland; IInternational Research Fellow, Ruhr University, Bochum, Germany
}

\begin{abstract}
The analysis of the intertwined reactions of Hong Kong and Mainland China to the 2008 Global Financial Crisis is considered in this study through the lenses of their stock markets. The GARCH-based analysis of stock market performance over the period December 2011December 2014 shows that trade and equity sectors were the sectors most affected by the global recession; volatility was prevalent on the Shanghai stock market, whereas volatility persistence characterised the Hong Kong stock market. The results also show that the two stock markets recovered quite quickly. Tight controls applied by the financial authorities helped ensure some stability during the crisis.
\end{abstract}

\section{ARTICLE HISTORY}

Received 11 June 2017

Accepted 12 March 2018

\section{KEYWORDS}

Global financial crisis; volatility; sectors and stock markets

\section{Introduction}

The 2008 Global Financial Crisis (GFC) created a situation of major stress, uncertainty and confusion regarding the appropriate actions that ought to be taken to counteract its impact on the world economy. China's mainland economy recovered relatively quickly from the GFC when compared with other major world economies, and this helped countries belonging to the Greater China region to develop and grow (Hong, Yoon, and Chang 2014).

The economic and financial implications of the GFC and their impact on the Chinese economy through its connections with and dependency on Hong Kong are examined here. This study looks at market integration policies in the region and their implications on the recovery process. The understanding of how the two economies adjusted in the aftermath of the crisis helps open a discussion on the main lessons learnt from the global financial turmoil. An analysis of the Asian region and its approach to deal with the effects of the aftershock is relevant due to the stability patterns that characterised the region over the period of distress. The study looks at measures that aim to minimise the impact of future shocks that could weaken both economic growth and development in the region and its international connections. Special attention is devoted to the case of China - given its economic weight in the Asian region - so as to gain a better understanding of how the Chinese Government has been and still is dealing with internal and external shockwaves. An issue of particular interest is the case of the financial and economic connections between China 
and Hong Kong in the background of recent concerns such as the September 2014 Umbrella Protest in Hong Kong and China's increasing momentum for financial liberalisation and sustainable growth. Since Hong Kong is a key financial centre in the region, and given its role in the internationalisation process experienced by the Chinese economy over the recent decades, it is necessary to consider the main challenges that the region is facing, and how they might destabilise potential growth and international relationships.

The analysis of the China-Hong Kong relationship in the aftermath of the GFC through the lenses of their stock markets is essential to understand dependencies in the region, and the way in which they might foster or threaten future economic development and growth. Furthermore, understanding the impact of global shocks and their effects in Hong Kong are relevant due to the spillover effects generated towards China and subsequently towards the Asian region.

The remainder of the paper is structured as follows: section two presents a literature review that briefly depicts the China-Hong Kong relationship. Section three offers a discussion of the data used and it briefly outlines the research methodology that was selected to support the study. In section four, a critical discussion of the research findings is presented with insights into the lessons that might be learnt from the Asian approach to the GFC. Finally, section five concludes the paper and offers some suggestions for further research.

\section{Literature review and rationale for the study}

Since the 1960s, East Asian region growth levels and social development have been remarkable. By 2010, Asia's share of global gross domestic product (GDP) had reached 35\% (Asian Development Bank 2012). At the centre of this success, two specific major achievements can be highlighted: (i) the strong links that the region has developed with the global economy and (ii) the reduction in poverty levels with middle-class numbers increasing to become a major force in the region. In spite of the GFC, East Asia emerged as a region of relative stability, owing partly to some lessons derived from the management of the 1997 Asian Financial Crisis (Kawai, 1999; Borthwick 2012). Nevertheless, the GFC did impact on some of Asia's core economic sectors, raising major concerns regarding the ability of the region to adapt to shocks originating from developed economies and harmful spillovers to the region. The most obvious and immediate transmission channels were trade and financial investment with the export sector and equity markets experiencing sharp declines across the region. Currency and credit markets were affected, and domestic demand softened as a result of global uncertainty. This sensitivity put into question the export-led growth strategies followed by many of these countries, including China, and the region's financial sector was severely affected, as foreign investors fled to safe havens. As a result of the world economic downturn, many Asian economies saw their trade and output levels decline dramatically. In particular, and despite its sustained positive growth performance (albeit at lower levels than before), China faced a severe decline in its exports (Figure 1) caused by its high exposure to the US market (Li, Willett, and Zhang 2012). China's exports fell by $17.5 \%$ in January 2009 and by $25.7 \%$ in February 2009 respectively when compared to corresponding months in 2008, marking the worst performance for the country in a decade and highlighting a certain fragility in its major economic fundamentals.

Even though the Chinese central government implemented a significant economic stimulus package in October 2008, its effects on the economy only partially offset the impact of the GFC (Fabre 2013). The country was nevertheless able to react overall in a swift manner 


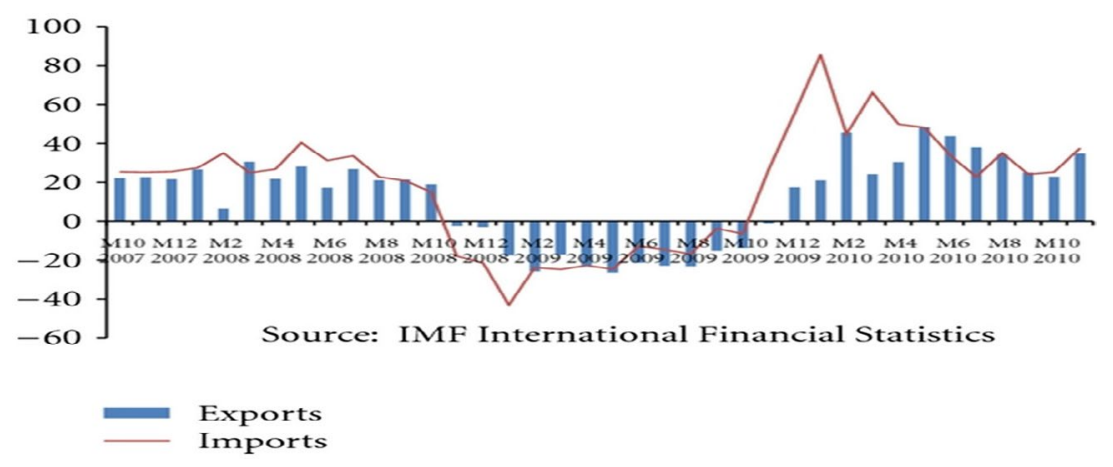

Figure 1. China's exports and imports during the GFC (2015).

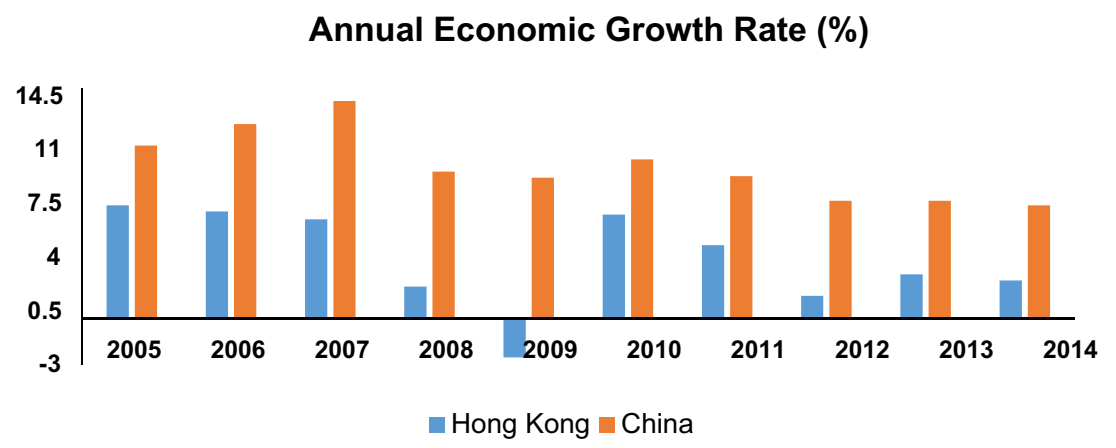

Figure 2. Hong Kong and China GDP growth rate (Source: World Bank statistics, 2015).

due to its strong fiscal and financial position, as the country enjoys significant levels of international reserves that facilitated the injection of liquidity into its economy. While growth still remained well above the international average, its decline was of the same order of magnitude as the one experienced by the United States. Figure 2 reflects a substantial slowdown of the Chinese economy that saw its annual growth rates fall from double digit figures (14.2\%) registered in 2007 to single-digit figures exhibited in 2008 (9.6\%) and 2009 (9.2\%), starting a new cycle of slower growth. This prompted the Beijing Government to further unleash its 'go global'strategy by focusing more systematically on diversified markets abroad such as the African continent for its mineral resources and the European Union in the midst of its euro crisis.

\subsection{Hong Kong's integration with Mainland China}

As can be seen from Figure 2, the Hong Kong Special Administrative Region (SAR) also suffered a sharp growth contraction in early 2009 , followed by a recovery that was stimulated by its closer economic relationship with China. By the end of 2008, Beijing's central government implemented significant investment measures such as the 'Outline of the Plan for the Development of Pearl River Delta (PRD)', and supplementary measures to the Closer Economic Partnership Arrangement (CEPA) were also put in place (Zhang and Tong 2009). Both plans' major goal was to foster co-operation and integration (both economic and political) between 
Hong Kong SAR and the mainland economy. This situation has given rise to some disquiet as could be attested by public discontent and protests in Hong Kong in September 2014.

The process of integration between Hong Kong and post-Mao China is not new. In the 1980 s and 1990s, cross-border manufacturing activities nurtured a great deal of direct investment coming into Mainland China's special economic zones. In the 1990s, Hong Kong started to promote the diversification and development of its financial system leading towards its development as a major financial hub in the region. Hong Kong's role as an international financial centre and its huge foreign exchange reserves have also helped boost China's economic development. Currently, the importance of Hong Kong's stock market is reflected by its ranking in the world's top 10 world stock markets. In addition, Hong Kong's economy is very dynamic, and it is characterised by significant holdings of foreign exchange reserves, by a large volume of banking transactions, by foreign trade which is facilitated by an international airport and by favouring high competitiveness levels. The favourable economic policies of China aided the creation of opportunities that furthered the integration between Hong Kong and China's Guangdong province leading in turn to the point where the two regional economies have become closely integrated. Consequently, and because of the strong links existing between the two economies, Hong Kong's export sector was also negatively affected by the GFC, plunging by $21.8 \%$ year on year in January 2009 (Zhang and Tong 2009). Domestic demand and investors' sentiment were at an all times low given the tighter credit market conditions, the lack of opportunities in the labour market and the negative wealth effect owing to the corrective effect on the local asset market. As in the case of China, Hong Kong's government acted quickly by implementing measures that aimed to create employment, support enterprises and stabilise the financial market.

\subsection{Mainland China and Hong Kong stock markets during the GFC}

Monitoring a country's stock market performance is relevant due to its impact on investors' confidence and consequential strategies to allocate funds across various investment portfolios. A financial and economic crisis leads to investors' risk aversion which triggers cautionary behaviour regarding investment and capital allocation. Investment portfolios are withdrawn from the distressed region and as a result, macroeconomic performance is negatively affected. A vicious circle starts, and the economy moves towards a situation where investors' low confidence translates into low consumption levels due to the negative impact on wealth, leading to further low investment levels. In this regard, the Hong Kong SAR economy has shown increased levels of sensitivity to recessions born in developed economies, given its strong dependence on those markets through its export and financial sectors. On the other hand, and as discussed above, China remained quite resilient to the 2008 shock.

The way the two economies' financial markets reacted to the GFC because of their interrelationship has given rise to very few published research papers. Early studies such as those of Chakravarty, Sarkar, and Wu (1998), and Yeh and Lee (2000) suggest that the stock markets of Mainland China and Hong Kong are interrelated showing different leverage and feedback effects. In particular, Hong Kong is found to exert a temporary influence on the B-Share market in the Shanghai and Shenzhen stock markets. A significant difference in regulations between the Shanghai and Hong Kong stock exchanges relates to the price limits set by the Chinese authorities on the Shanghai stock exchange. This price limit is equal to $10 \%$ of the last trading day's settlement price (Zhang and Jaffry 2015). The literature in the field looking 
at the efficiency of imposing price limits is quite controversial and scarce, with most existing studies only focusing on the analysis of tranquil periods. As documented by Wang, Chong, and Chan (2014, p.27), China's stock markets were volatile during the GFC, leading to a significant delay in the efficiency of the price'discovery' mechanism during the market turmoil. For the initial stages of the GFC, Qiao, Chiang, and Wong (2008) found evidence of unidirectional return spillover effects running from the A-Share Shanghai stock exchange to the Hong Kong stock market. However, Mohammadi and Tan (2015) did not find evidence of return spillovers between the Hong Kong and Mainland China stock markets.

Zhang and Jaffry (2015) found a bidirectional volatility spillover effect between the Hong Kong and China main stock markets during the GFC period. The research findings indicate that during the crisis period the economic and financial ties between Mainland China and Hong Kong stock markets were enhanced. On the other hand, the authors also identified a lack of direct influence on Mainland China's market, as the effects of the global recession flowed into the region through the Hong Kong stock market - which is more developed and sophisticated - with evidence of daily bidirectional volatility spillover effects. Hong Kong has benefited China by serving as a financial gateway and contributing to the development of strategic linkages with the global economy. Since the retrocession of Hong Kong to China in 1997, China has stimulated Hong Kong's economy through favourable policies such as allowing local banks to conduct more businesses for corporate clients and local firms, to issue bonds, to apply for bank loans/credit and to finance projects and trade which are settled in the Chinese currency.

The subprime crisis enhanced the economic and financial links between Mainland China and Hong Kong, in so far that the Hong Kong stock market played a considerable role, in acting as a conducive channel of global financial risks which flowed into the region and which led to the generation of significant market volatility in the Chinese stock market (Singhania and Anchalia 2013; Zhang and Jaffry 2015). The increased levels of integration of the Chinese stock market in the Asian region explain its exposure to the financial turmoil, with Hong Kong having been identified as the main conduit of financial instability. Wang (2014) noted that even before the crisis, Hong Kong displayed very high levels of influence in the Chinese stock market. However, after the financial turmoil, the influence of Hong Kong diminished, and China seemed to be taking a more interactive and influential role in the region (Huyghebaert and Wang 2010). Asymmetric spillover effects between the stock markets of mainland China and Hong Kong therefore existed before and after the 2008 financial crisis, with impacts subject to variations depending on the states of the stock markets, as investors reactions are different depending on bull and bear markets, signalling the dynamic behaviour of these markets (Zhu, Tang, and Guo 2017).

The global financial crisis led to the development of the pilot programme'Shanghai-Hong Kong Stock Connect'; indeed, in April 2014, the Chinese Securities Regulatory Commission and the Securities and Futures Commission made a joint announcement approving a pilot programme that aimed to establish mutual access between the Mainland China and Hong Kong stock markets (Huo and Ahmed 2017). The programme was launched on 17 November 2014 and it is considered as a landmark event in the reform of the Chinese stock markets which seeks to relax restrictions and reshape financial structures in both the Chinese and Hong Kong stock markets. Raine and Adams (2015) highlight that the enhanced openness of the Mainland Chinese stock markets will contribute to improvements in market efficiency, and market activity, but at the same time it will lead to a rise in the market risk level, since 
foreign investors generally tend to be more informed investors, and since their market participation can lead to higher levels of volatility. The success of the 'Shanghai-Hong Kong Stock connect' initiative offers a valuable operational experience which can help China to keep developing and strengthening its financial connections in the region while fostering needed reforms that contribute to the financial liberalisation of the Chinese stock markets.

The main findings from the reviewed literature offer relevant evidence of significant economic and financial ties existing between Hong Kong SAR and China, although the overall relationship has evolved into a growing level of (political) intervention from Mainland China, whose economic and financial role is intensifying; concomitantly, the dominance exerted by the Hong Kong financial hub seems to be waning in the region.

\subsection{The fiscal and monetary stimulus programme}

The Chinese economy was able to exhibit robust economic growth during the GFC, despite the damage that the financial turmoil caused to many of the nation's main export markets (Su 2009; Burdekin et al. 2012). China's Government managed the impact of the GFC through a large fiscal stimulus programme, coupled with a substantial monetary easing policy and actions to spur banks to lend more (Peaple 2008). The Chinese authorities were able to implement a 'moderately accommodative monetary policy' with the aim of strengthening its economy by fostering the growth of domestic credit and money supply. From September to December 2008, the People's Bank of China (PBC) lowered the benchmark interest rates on deposits and on loans five times, and the reserve ratio four times. Moreover, by the end of 2008, the PBC abolished credit quota constraints on commercial banks and urged them to expand their lending credits. As a result, the economy experienced an explosion in the growth rate of money supply and of incremental credit. Nonetheless, the implementation of a loose monetary policy manifested itself in increased levels of volatility in the Chinese stock market. As the Chinese economic slowdown became apparent in the last quarter of 2008, the government shifted to a 4 trillion RMB pro-growth stimulus programme over a two-year period that aimed to counteract the effects of the GFC (He, Zhang, and Zhang 2009). The government stimulus package targeted new investments in key areas such as housing, rural infrastructure, transportation, health and education, environment, industry and disaster rebuilding, with public infrastructure taking a prominent role in the plan (Zhang, Zhang, and Breece 2011). After the stimulus package was introduced, economic indicators measuring consumption and industrial production recovered very quickly and the Shanghai Composite Index climbed from 1820.81 points on 31 December 2008 to 2,477.57 in 20 April 2009 , signalling a significant rise of $36 \%$ over a short period of time.

Whalley and Zhao (2013) studied the relative importance of expenditure stimulus and tax stabilisation after the onset of the 2008 crisis; their findings show that government spending and revenue stimulus from automatic revenue responses both contributed to the speedy recovery of the Chinese economy from the crisis, with the tax side of the programme playing a more significant role than the expenditure side. Domestic demand was boosted by the implementation of a huge fiscal stimulus package that was combined with a call for the nation's banks to boost lending rates. The stimulus programme followed by the Hong Kong Government relied on strategies that aimed to improve the competitiveness of its economy. The main mechanism to cope with the financial disruption was mainly focused 
on the promotion and development of infrastructure supporting new industries; this helped add a new dimension to Hong Kong's economic model with significant ties to and heavy dependence on state-owned businesses; in turn, this has led to the domination in the Hong Kong city of financial and commercial interests (Fung 2014).

Huang (2010) claims that the impact of the GFC on China's financial system was relatively mild due to its lack of financial depth and sophistication, as well as to its isolation from the global markets. At the same time, China's domestic responses through its stimulus programme was quite effective enabling the economy to achieve sustained economic expansion and restoring market confidence, but simultaneously, raising concerns on the side effects for China's financial regulatory system. The financial crisis exposed several problems (Fabre 2013) that included structural imbalances, lack of regulatory independence, challenges of financial modernisation and new issues regarding banking regulation, all areas of major concern that need to be carefully considered by the Chinese authorities, as they search for a more visible and stronger role in the global capital markets.

\section{Data and research methodology}

The selected research methodology rests on an analysis of the Hang Seng Index and the Shanghai Stock Exchange 50 (SSE50) Index as well as on the stock index of five selected sectors. This analysis is aimed at shedding some light on stock market performance over a three-year period (December 2011-2014), a period that mirrors the effects of the GFC in the medium term. By the end of 2011, the effects of the October 2008 stimulus package in China had already started to fade away (Fabre 2013) making the selected period an appropriate period of analysis. A volatility framework based on the well-known $\operatorname{GARCH}(1,1)$ is used to offer some insights into the performance of these stock markets.

To ensure that the time series comply with stability and stationarity properties, the Augmented Dickey-Fuller test and the Phillips-Perron test were implemented. The econometric testing continues with the estimation of an appropriate Vector Autoregressive framework to ensure that the optimal number of lags was identified. The testing procedures encompassed the implementation of ARCH modelling to help identify the existence of ARCH effects affecting the series, and that aimed to confirm the existence of heteroskedastic behaviour. Finally, the volatility model selected to support the empirical analysis was the wellknown and generally accepted approach for testing volatility, i.e. the Generalized Autoregressive Conditional Heteroskedasticity (GARCH) model introduced by Bollerslev (1986), with the basic GARCH $(1,1)$ being estimated. The Bollerslev generalized ARCH model, or $\operatorname{GARCH}(p, q)$, is outlined below:

$$
y_{t}=\alpha+\beta^{\prime} x_{t}+\varepsilon_{t}
$$

where $\varepsilon_{t} \mid \Omega_{t} \sim \operatorname{iid~N}\left(0, h_{t}\right)$

$$
h_{t}=\omega+\sum_{i=1}^{p} \alpha_{i} h_{t-i}+\sum_{j=1}^{q} \beta_{j} \varepsilon_{t-j}^{2}
$$

The GARCH model conditions the value of the variance scaling parameter $h_{t}$ to both past values of the shocks (captured by the lagged squared residual terms), and its own past values (captured by the lagged $h_{t}$ terms). The simplest GARCH $(1,1)$ model was considered as an 


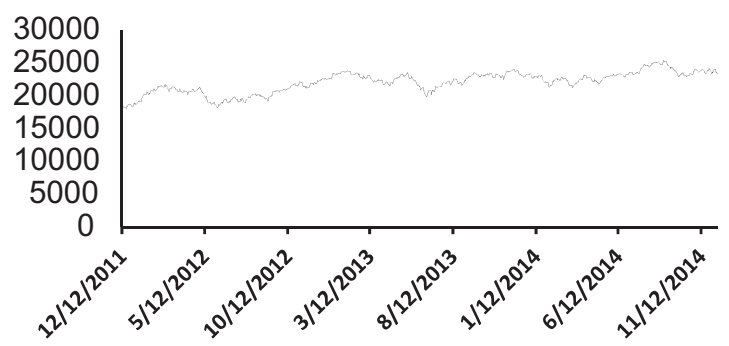

Figure 3. Hang Seng Index.

Source: DataStream (2016) - adjusted by the authors.

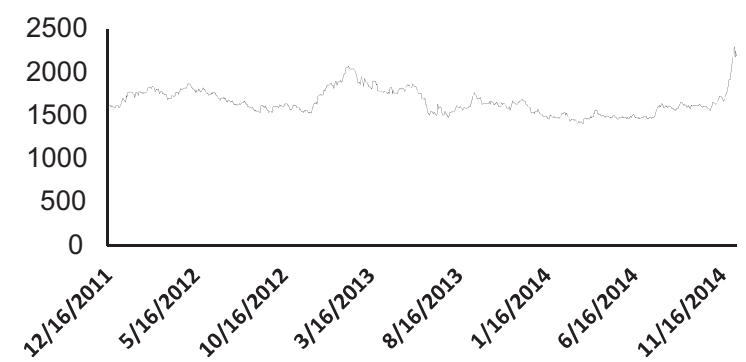

Figure 4. Shanghai Stock Exchange 50.

Source: DataStream (2016) - adjusted by the authors.

optimal approach to support this study, as the main purpose was the identification of volatility persistence affecting the Hang Seng Index and the SSE50 to measure for market efficiency and signs of recovery. The variance equation is defined below:

$$
h_{t}=\omega+\alpha_{1} h_{t-1}+\beta_{1} \varepsilon_{t-1}^{2}
$$

where the long-run variance is captured by $\omega$, today's variance and previous periods' values are measured by the $a$ coefficient, and $\beta$ is the coefficient to compute today's variance and previous time periods' variance. Therefore, $\omega$ is the long-run volatility, $a$ measures volatility pikes, and $\beta$ looks after volatility persistence effects. The study focuses on the $\alpha$ and $\beta$ coefficients, as they are the ones that measure volatility persistence and they also identify the approximated number of days during which the shock lasted in the markets; this gives an insight into the lasting effects of market shocks and their potential to spillover to the real economy.

\section{Results and contribution to the field of knowledge}

\subsection{Findings}

Figures 3-5 depict the behaviour of both the Hang Seng Index and the SSE50 Index over the chosen time period. The Hang Seng Index registered a minor positive trend over the period implying a behaviour which appeared to be quite stable. On the other hand, the SSE50 showed more instability with a significant drop registered towards the end of 2013 and more stable behaviour until the end of 2014 , when the index registered significant jumps 


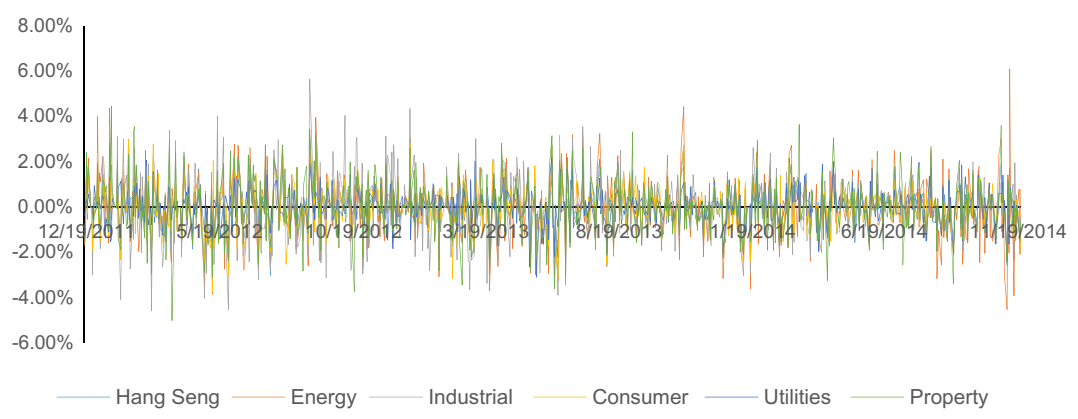

Figure 5. Hang Seng Index \& sectors changes.

Source: DataStream (2016) - adjusted by the authors.

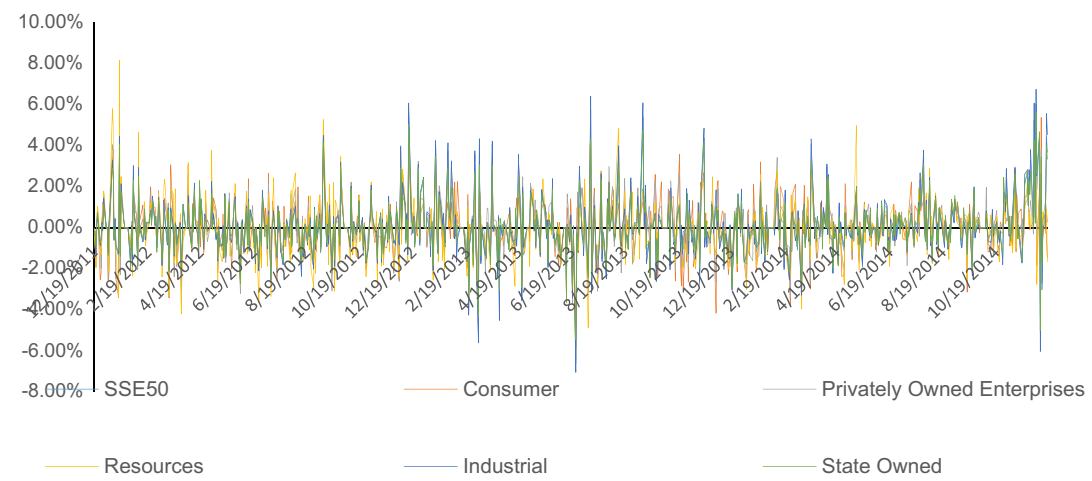

Figure 6. Shanghai Stock Exchange 50 and sector changes.

Source: DataStream (2016) - adjusted by the authors.

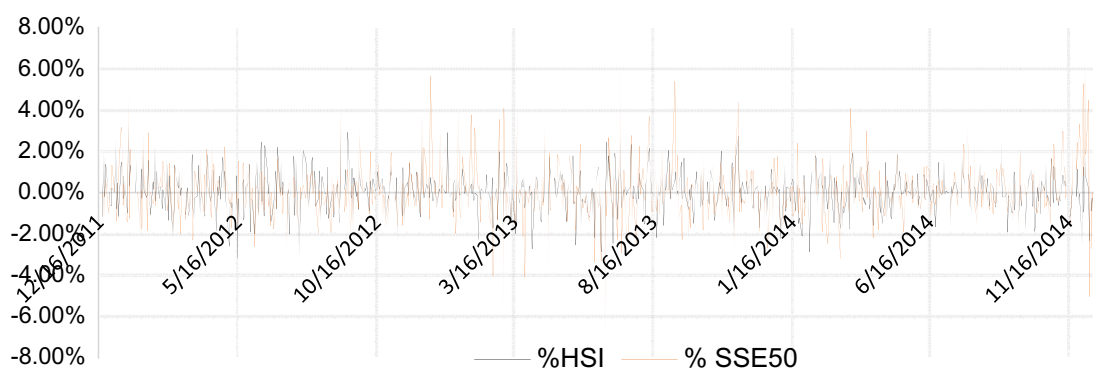

Figure 7. Hang Seng Index and Shanghai Stock Exchange 50 Price Changes.

Source: DataStream (2016) - adjusted by the authors.

in the last month of the year with increases during the following days: the second $(5.27 \%)$, the fourth (6.07\%) and the eighth (4.48\%). Figure 3 gives an indication of how the Hong Kong Hang Seng Index and its decomposition into indices mirroring a number of selected sectors evolved after the financial shock. It can be seen how the property sector is the one that has been subjected to most variations. Relative stability on the Hong Kong stock exchange contrasts with more erratic behaviour in Shanghai where the SSE50 registered changes (Figure 5-7). 
Table 1. Index and sectors volatility.

\begin{tabular}{|c|c|c|c|c|c|c|}
\hline Coefficients & Hang Seng ${ }^{a}$ & Consumer goods & Energy & $\begin{array}{l}\text { Consumer } \\
\text { services }\end{array}$ & Industries & Utilities \\
\hline $\bar{A}$ & $\mathrm{n} / \mathrm{a}$ & 0.019 & 0.032 & 0.045 & 0.036 & 0.057 \\
\hline B & $\mathrm{n} / \mathrm{a}$ & 0.967 & 0.941 & 0.9 & 0.96 & 0.885 \\
\hline$a+\beta$ & $\mathrm{n} / \mathrm{a}$ & 0.986 & 0.973 & 0.945 & 0.996 & 0.942 \\
\hline Days & $\mathrm{n} / \mathrm{a}$ & 49 & 25 & 12 & 173 & 12 \\
\hline Coefficients & SSE50 & Consumer goods & Resources & $\begin{array}{c}\text { Privately owned } \\
\text { enterprises }\end{array}$ & Industries & State owned \\
\hline$A$ & 0.069 & 0.055 & 0.084 & 0.063 & 0.073 & 0.07 \\
\hline B & 0.88 & 0.86 & 0.83 & 0.89 & 0.89 & 0.85 \\
\hline$a+\beta$ & 0.949 & 0.915 & 0.914 & 0.953 & 0.963 & 0.92 \\
\hline Days & 13 & 8 & 8 & 14 & 18 & 8 \\
\hline
\end{tabular}

aThe Hang Seng performance was not captured by the GARCH model as the coefficients were negative not complying with the basic guidelines of the model for stability of the variance.

Table 1 presents the empirical findings derived from our volatility test. Since the GARCH model did not capture the Hang Seng performance over the whole selected period, as the results were non-stationary in variance, the results obtained from the estimation of the $\operatorname{GARCH}(1,1)$ do not allow the development of an appropriate comparative analysis between the Hang Seng and the SSE50 Indices. However, the comparative analysis across sectors and economies is most revealing. In particular, the results highlight how the Hang Seng sectors are affected by significant volatility persistence effects when compared to the SSE50 and to the sectoral indices in Shanghai. This implies that market volatility was short lived for the SSE50 selected sectors, and that the Hang Seng sectors were less efficient than the SSE50 sectors over the sampled period. The longest volatility persistence was registered for Hong Kong's industrial sector which needed up to 173 days to stabilise, thereby indicating inefficiencies and long-lasting aftershock effects (Appendix 1).

The correlation between Chinese and other Asian equity markets increased during the global financial crisis, as a result of investors' interest in China; the latter was more due to financial instability and uncertainty in developed economies, rather than to improvements regarding liberalisation and deepening of financial transactions during the period, as China did not implement major policy measures during the period (Fabre 2013; Glick and Hutchison 2013). Furthermore, the street protests in Hong Kong's towards the end of 2014 raised major concerns among the international community and its pool of investors. There were some concerns that Hong Kong would be destabilised and its position as a major financial centre would suffer as a result. However, the events that disturbed the territory and that unfolded over a few weeks did not seem to generate persistent effects in the financial system. In short, Hong Kong's stock market has not been destabilised by the demonstrations, as the Hang Seng Index exhibited a strong performance during the first months of the year 2015 and as it has been gaining confidence back and recovering the positions that were lost during the times of the unrest.

\subsection{Some lessons learnt from the $2008 \mathrm{global}$ financial crisis}

An important issue to consider regarding the importance of financial systems is that their primary function is to facilitate the allocation of resources to activities that ensure economic growth and development. Therefore, a well-functioning and healthy financial system ensures 
sustainable economic growth, whereas malpractices by its major players (for instance poor regulation by the relevant regulatory authorities) lead to crises which have tended to come in cycles. In this regard, crises offer an opportunity to learn from them, and this learning effect ought to be used to enhance and strengthen a country's economic and financial system. Too often, learning outcomes seem to be relegated to the region affected and to specific moments in time, and the crisis moments are easily forgotten when the region starts to exhibit signs of recovery. Luckhurst (2012) argues that the failure of leading international policy-makers to implement effective policies to handle situations of economic and financial distress ends up exacerbating the impact, dimension and lasting effects of a crisis. Therefore, it is imperative that policy-makers be aware of the existence of downward cycle trends in the economy and of the early economic and financial signals that help them prevent or at least minimise the occurrence of major crises.

The findings by Hong and Tang (2012) indicate that stimulative policies applied by governments in developing Asia were supportive of economic activity, with public consumption being the essential driver of growth when the region entered into recession in the fourth quarter of 2008. In this regard, the Asian region appears to be more reliant on fiscal policies than on monetary policies as a way to counteract GDP slumps.

In the case of Hong Kong, the main policy has followed a conservative approach. Hong Kong developed an economic and financial framework that promotes stability, the origins of which can be found from the lessons learnt during the Asian financial crisis (Kawai 2009). For instance, the housing market is a major source of concern due to its impact on the real economy. Back in the 1990s, housing prices in Hong Kong showed significant signs of misalignment with macroeconomic fundamentals, and the Hong Kong dollar was overvalued. The property market collapsed, and housing prices dropped significantly. In 1998, the Hong Kong Monetary Authority intervened in the equity market to counter the strategy of hedge funds (who had taken short positions in stock futures) leading towards a quick recovery of the Hang Seng index. The crisis did not lead to a banking crisis and there was no need to bail out banks (He 2013), as became the trend approach in developed countries during the global turmoil.

In the case of Mainland China, the government has re-established and developed two main stock exchange markets (Shanghai and Shenzhen) that are subject to close monitoring and control. These markets are seen as an additional source of finance for the large stateowned enterprises. China's approach to financial operations is based on a tight monitoring of activities which seeks to control and heavily regulate financial transactions at both the domestic and cross-border levels. Operations conducted by financial institutions have strict restrictions on the use of derivatives and sophisticated financial instruments. The country has moved and is moving slowly and in a cautions manner towards financial liberalisation and openness with some steps made to authorise residents and non-residents alike to use the renminbi to trade, invest, borrow and invoice outside of China (McCauley 2011; Prasad and Ye 2007; Andreosso-O'Callaghan and Gottwald, 2013). The banking sector is also heavily controlled regarding capital movements so as to limit external competition. At the same time, heavy restrictions have been imposed on international investment by residents, banning operations that involve overseas securities.

In this regard, some similarities can be identified between Hong Kong and Mainland China in terms of their regulatory and conservative approach to their financial systems. Both have implemented protective measures to look after their financial systems through the 
enactment of policies and measures that have helped minimise the impact of external shocks and spillover effects derived from global economic slumps. Chinese capital controls have been effective in partly 'decoupling' Chinese financial markets from those of the USA and elsewhere (see Cheung, Menzie, and Eiji 2005; Ma and McCauley 2010; Prasad and Ye 2007). The main outcome regarding China's approach to its financial system, indicates that some level of liberalisation in financial markets has taken place, but that tight controls and surveillance on operations that involve international transactions remain in place, a situation that contributed to diminish the spillover effects from the GFC to the country's financial system.

\subsection{Going forward}

Notwithstanding its current low level of participation in global capital markets, China is expected to play an increasing role in the future. Despite the fact that China is increasingly integrated into the global economy, the pace of integration is uneven across the trade and financial sectors (Cheung, Steinkamp, and Westermann 2016). The problem of global imbalances remains an issue that has serious implications in terms of illicit capital flows and official flows that have experienced large swings in 2015 (Chinn 2013).

Under President Xi leadership style, China has implemented several significant initiatives in the area of foreign policy; the Chinese leader is sending clear signals of cooperation towards the countries of Southeast Asia and further afield. One such initiative is the 'Silk Road Economic Belt' and the 'Twenty-first Century Maritime Silk Road' that was announced in October 2013 and that together are known as the 'One Belt, One Road' (OBOR) initiative (Nie 2016). OBOR is a very ambitious initiative that aims to promote joint development, common prosperity and co-operation between China and many countries across Asia and the Middle East. The OBOR initiative can be used as a main instrument to reshape international rules and norms, and to influence the global economic order; this would help President $X i$ to achieve its economic and political agenda that is outlined domestically as 'China's dream' and internationally as 'national rejuvenation'. With OBOR, China intends to play a more proactive and influential role in terms of governance structures in the Asia-Pacific region and globally. Over the second half of 2008, China's economic growth reliance on the outside world became very clear, and a need to change its existing economic model was highlighted.

The successful implementation of the OBOR initiative could enhance China's geopolitical interests and as a result increase its sphere of influence (Ploberger 2017). According to Yu (2017), the OBOR initiative is a centrepiece of the Chinese leadership's new foreign policy that looks to project the economic and political ascendancy of China in the global arena. A major development of OBOR is the creation of the Asian Infrastructure Investment Bank (AIIB) that demonstrates that China is starting to take control of its leadership role and that it is positioning itself as a rising global power (Thuan 2017). The scale and pace of change in China's foreign policy under President Xi have been unprecedented. The development of the AIIB has major implications for the development and consolidation of the Chinese financial system, as the AllB and the New Development Bank (NDB) can mobilise resources for infrastructure and sustainable projects, bringing to central stage the urgent need of developing a strong, competitive and reliable financial system (Das 2017). 


\section{Conclusions}

In spite of their relative insulation from world financial markets, the economies of both Hong Kong and Mainland China were affected by a strong hit in their trade sector, while their stock markets registered a substantial loss after the GFC. Our findings show that the Shanghai stock exchange was relatively unstable during the December 2011-2014 period, whereas the Hong Kong stock exchange was affected by significant volatility persistence effects during the same period. Our results also show that the economic and financial linkages between Hong Kong and Mainland China have been enhanced in the aftermath of the GFC. A timely intervention by the fiscal and monetary authorities injecting appropriate liquidity through a stimulus package into the economy and the solidity of the financial system helped the region to weather the negative effects of the economic downside in a better manner than in the case of most developed economies, at least in the short term.

Several lessons can be drawn from this analysis: the first one relates to the management and prevention of international shocks, and to the important role of the supervisory financial authorities. A second issue involves determining whether developed economies can learn anything from the approach followed by Hong Kong and China to enhance a certain degree of financial liberalisation, while at the same time keeping the economy relatively insulated from major financial external shocks. A third issue is the ambitious economic and political agenda settled by President Xi aimed at aiding China to play a more proactive role in the economic architecture of the Asia-Pacific region and in global governance structures. The OBOR initiative will strengthen China's financial dimension worldwide and this could lead to a further and major restructuring of the global economic and financial architecture.

\section{Disclosure statement}

No potential conflict of interest was reported by the authors.

\section{Notes on contributors}

Lucía Morales is a lecturer in Finance. The author's major research interests are in the following areas: Emerging Economies, Economic and Financial Crises, Market Uncertainty, Economic and Financial Integration and Education.

Bernadette Andreosso-O'Callaghan's major research interests are in the following areas: Economic Integration (Asia and Europe compared), EU-Asian economic relations (trade, investment and technology transfer), Economic Growth and Structural change in Asian countries. Other research interests include: Development Economics, Input-Output Analysis and History of Economic Thought.

\section{ORCID}

Lucía Morales (D) http://orcid.org/0000-0002-9111-813X

\section{References}

Andreosso-O'Callaghan, B., and J.-C. Gottwald. 2013. "How Red is China's Red Capitalism? Continuity and Change in China's Financial Services Sector during the Global Crisis." Asia Pacific Business Review 19 (4): 444-460. 
Asian Development Bank. 2012. How Can Asia Respond to Global Economic Crisis and Transformation?. Mandaluyong City: Asian Development Bank.

Bollerslev, T. 1986. “Generalized Autoregressive Conditional Heteroskedasticity." Journal of Econometrics 31: 307-327.

Borthwick, O. 2012. "The Crisis and South Korea." In The Transformation of Asia in a Global Changing Environment, edited by B. Andreosso-O'Callaghan and P. Herrmann, 93-110. New York, NY: Nova Science Publishers.

Burdekin, R. C. K., J. R. Barth, F. M. Song, and Z. Zhou. 2012. "China after the Global Financial Crisis." Economics Research International 12: 1-3. Hindawi Publishing Corporation.

Chakravarty, S., A. Sarkar, and L. Wu. 1998. "Information Asymmetry, Market Segmentation and the Pricing of Cross-Listed Shares: Theory and Evidence from Chinese a and B Shares." Journal of International Financial Markets, Institutions and Money 8: 325-356.

Cheung, Y.W., C. Menzie, and F. Eiji. 2005. “Dimensions of Financial Integration in Greater China: Money Markets." Banks, and Policy Effects, International Journal of Finance and Economics 10: 117-132.

Cheung, Y.-W., S. Steinkamp, and F. Westermann. 2016. "China's Capital Flight: Pre- and Post-Crisis Experiences." Journal of International Money and Finance 66: 88-112.

Chinn, M. D. 2013. "United States, China, and the Rebalancing Debate: Misalignment, Elasticities, and the Saving-Investment Balance." In The Evolving Role of China in the Global Economy, edited by Y.-W. Cheung and J. De Haan, 17-51. Cambridge, MA: MIT Press. (Chapter 11).

Das, K Ch. 2017. "The Making of One Belt, One Road and Dilemmas in South Asia." China Report 53 (2): 125-142.

Fabre, G. 2013. "The Lion's Share - What's behind China's Economic Slowdown?" Fondation Maison des Sciences de l'Homme, Octobre, Working Papers Series, No. 53.

Fung, K. K. 2014. "Financial Crisis and the Developmental States: A Case Study of Hong Kong." International Journal of Social Welfare 23: 321-332.

Glick, R., and M. Hutchison. 2013. "China's Financial Linkages with Asia and the Global Financial Crisis." Federal Reserve Bank of San Francisco. Working Paper Series 2013-12.

He, D. 2013. "Hong Kong's Approach to Financial Stability." International Journal of Central Banking March 2013 Issue.

He, D., Z. Zhang, and W. Zhang. 2009. “How Large will be the Effect of China's Fiscal Stimulus Package on Output and Employment?" Pacific Economic Review 14: 730-744.

Hong, K., and H. C. Tang. 2012. “Crises in Asia: Recovery and Policy Responses." Journal of Asian Economics 23: 654-668.

Hong, M. G., B. J. Yoon, and K. H. Chang. 2014. "The Volatility Dynamics of the Greater China Stock Markets." Asia-Pacific Journal of Financial Studies 43: 721-738.

Huang, H. 2010. "China's Legal Responses to the Global Financial Crisis: From Domestic Reform to International Engagement." Asian Law 12: 157-181.

Huo, R., and A. D. Ahmed. 2017. "Return and Volatility Spillovers Effects: Evaluating the Impact of Shanghai-Hong Kong Stock Connect." Economic Modelling 61: 260-272.

Huyghebaert, N., and L. Wang. 2010. “The Co-movement of Stock Markets in East Asia. Did the 19971998 Asian financial Crisis Really Strengthen Stock Market Integration?" China Economic Review 21 (1): 98-112.

Kawai, M. 1999. "The East Asian Currency Crisis: Causes and Lessons." Contemporary Economic Policy 16 (2): 157-172.

Kawai, M. 2009. "The Impact of the Global Financial Crisis on Asia and Asia's Responses Crisis Developments and Long-Terms Global Responses: Insights from Asia and Europe." AEEF Conference, Kiel, 7th July 2009. Asian Development Bank Institute. Accessed https://www.ifw-kiel.de/konfer/2009/ masahiro-kawai

Li, L., T. D. Willett, and N. Zhang. 2012. "The Effects of the Global Financial Crisis on China's Financial Market and Macroeconomy." Hindawi Publishing Corporation. Economics Research International 2012: 1-6.

Luckhurst, J. 2012. "Governance and Democratization since the 2008 Financial Crisis." Politics and Policy 40: 958-977. 
Ma, G. and R. McCauley. 2010. “Do China's Capital Controls Still Bind? Implications for Monetary Autonomy and Capital Liberalization." BIS Working Paper no.233.

McCauley, R. 2011. "Renmimbi Internationalisation and China's Financial Development." Bank for International Settlements Quarterly Review (December) 41-56.

Mohammadi, H., and Y. Tan. 2015. "Return and Volatility Spillovers across Equity Markets in Mainland China, Hong Kong and the United States." Econometrics 3: 215-232.

Nie, W. 2016. "Xi Jinping's Foreign Policy Dilemmna: One Belt, One Road or the South China Sea?" Contemporary Southeast Asia 38 (3): 422-444.

Peaple, A. 2008. "As the Global Economy Worsens, China Looks to Its Own." Harvard Asia Quarterly 12 (1): 54-59. (Cambridge, MA).

Ploberger, C. 2017. "One Belt, One Road - China's New Grand Strategy." Journal of Chinese Economic and Business Studies 15 (3): 289-305.

Prasad, E. and L. Ye. 2007. "The Renmimbi's Role in the Global Monetary System." In Asia's Role in the Post-Crisis Global Economy, edited by R. Glick and M. M. Spiegel, 383-387. San Francisco, CA: Federal Reserve Bank of San Francisco.

Qiao, Z., T. C. Chiang, and W.-K. Wong. 2008. "Long-Run Equilibrium, Short-Term Adjustment, and Spillover Effects across Chinese Segmented Stock Markets and the Hong Kong Stock Market." Journal of International Financial Markets Institutions \& Money 18: 425-437.

Raine, G. B., and S. D. Adams. 2015. “Navigating the Shanghai-Hong Kong Stock Connect: Relevance, Risks, and Practical Considerations for Investment Advisers." Invest Lawyer 22 (11): 21-29.

Singhania, M., and J. Anchalia. 2013. "Volatility in Asian Stock Markets and Global Financial Crisis." Journal of Advances in Management Research 10 (3): 333-351.

$\mathrm{Su}, \mathrm{M}$. 2009. “China: Unscathed through the Glboal Financial Tsunami." China \& World Economy 17: 24-42.

Thuan, N. Q. 2017. "China's Strategic Adjustments: Impact on the World, Region and Vietnam." China Report 53 (3): 367-385.

Wang, L. 2014. “Who Moves East Asian Stock Markets? The Role of the 2007-2009 Global Financial Crisis." Journal of International Financial Markets, Institutions and Money 28: 182-203.

Wang, D., T.T. L. Chong, and W. H. Chan. 2014. "Price Limits and Stock Market Volatility in China." Munich Personal RepEc Archive. MPRA Paper No. 54146, posted 7. March 2014 07:55 UTC. Accessed http:// mpra.ub.uni-muenchen.de/54146/

Whalley, J., and X. Zhao. 2013. "The Relative Importance of the Chinese Stimulus Package and Tax Stabilization during the 2008 Financial Crisis." Applied Economics Letters 20: 682-686.

Worldbank.org. (2015). "The World Bank, World Bank Statistics." Accessed http://data.worldbank.org/

Yeh, Y. H., and T. S. Lee. 2000. "The Interaction and Volatility Asymmetry of Unexpected Returns in the Greater China Stock Markets." Global Finance Journal 11: 129-149.

Yu, H. 2017. "Motivation behind China's 'One Belt, One Road' Initiatives and Establishment of the Asian Infrastructure Investment Bank." Journal of Contemporary China 26 (105): 353-368.

Zhang, Q., and S. Jaffry. 2015. “Global Financial Crisis Effects on Volatility Spillover between Mainland China and Hong Kong Stock Markets." Investment Management and Financial Innovations 12: 26-34.

Zhang, Y., and S. Y. Tong. 2009. "Hong Kong's Economy in the Financial Crisis." EAl Background Brief No.448.

Zhang, C-si, Da-Y Zhang, and J. Breece. 2011. "Financial Crisis, Monetary Policy, and Stock Market Volatility in China." Annals of Economics and Finance 12 (2): 371-388.

Zhu, H., Y. Tang, and P. Guo. 2017. "Asymmetric Spillover Effects between the Shanghai and Hong Kong Stock Markets: Evidence from Quantile Lagged Regression." Applied Economics 49 (9): 886-902. 


\section{Appendix 1}

\section{Shanghai stock exchange (SSE 50) sectors}

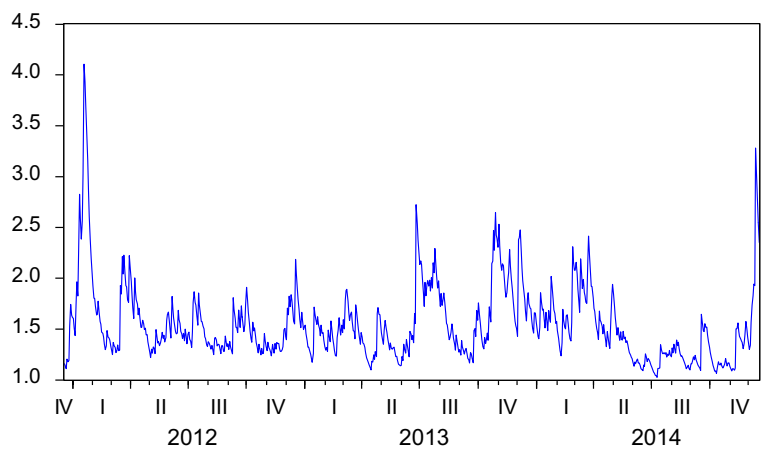

Figure 8. Consumer.

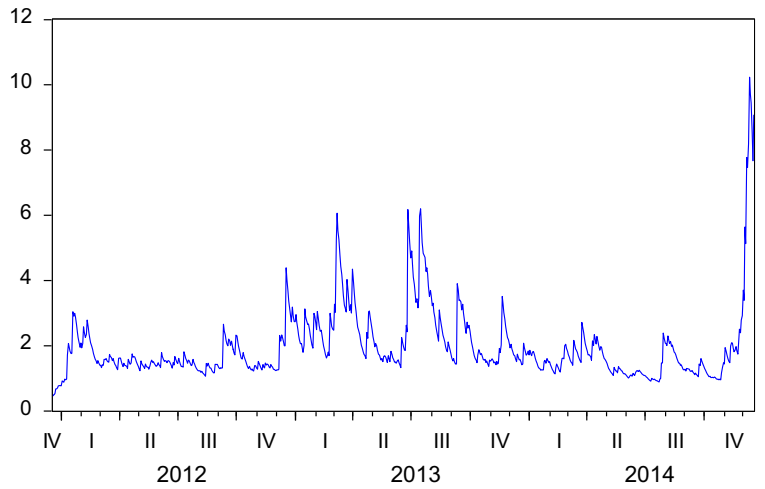

Figure 9. Industrial.

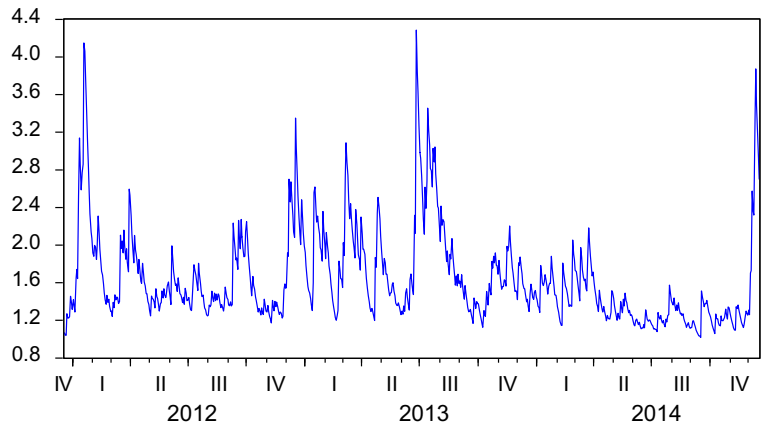

Figure 10. Privately owned enterprises. 


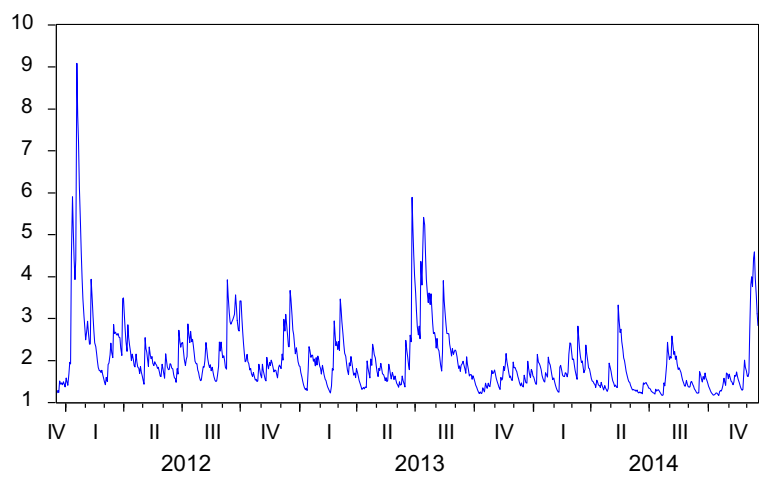

Figure 11. Resources.

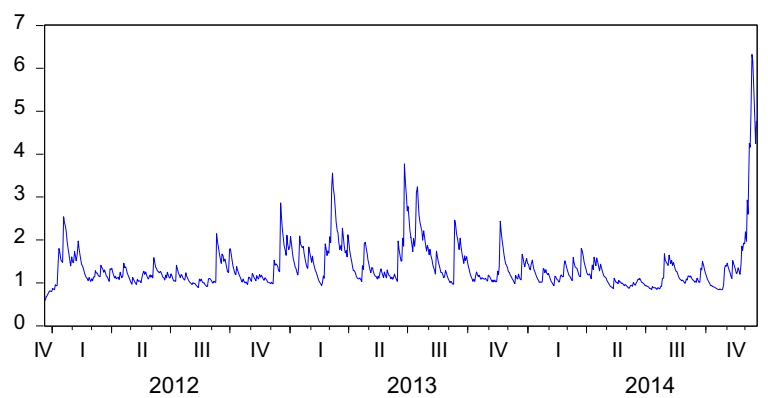

Figure 12. State-owned.

\section{Hang Seng Index Sectors}

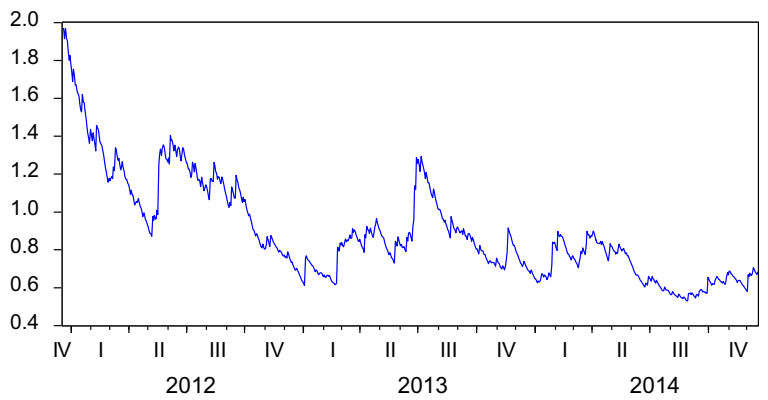

Figure 13. Consumer. 


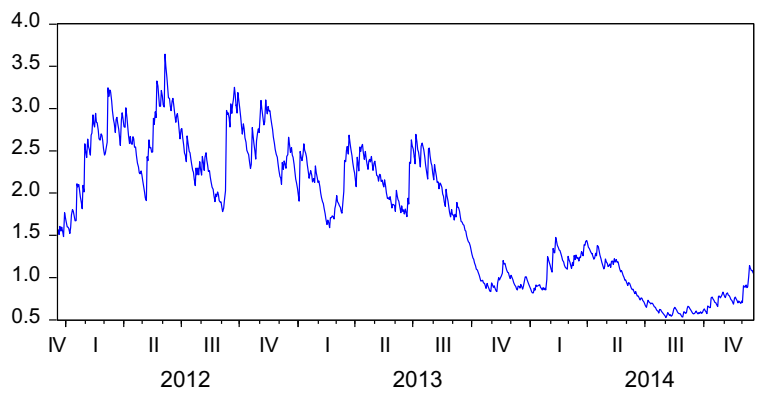

Figure 14. Industrial.

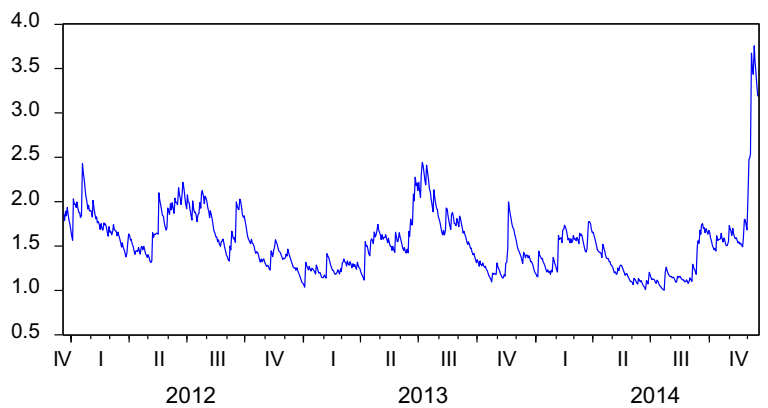

Figure 15. Energy.

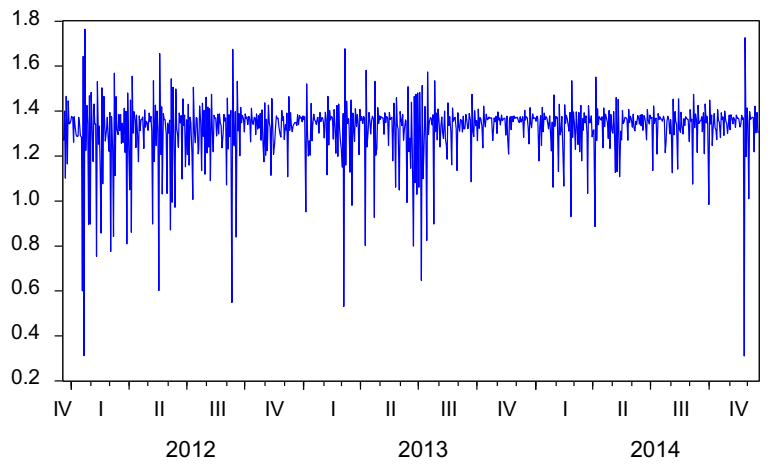

Figure 16. Property.

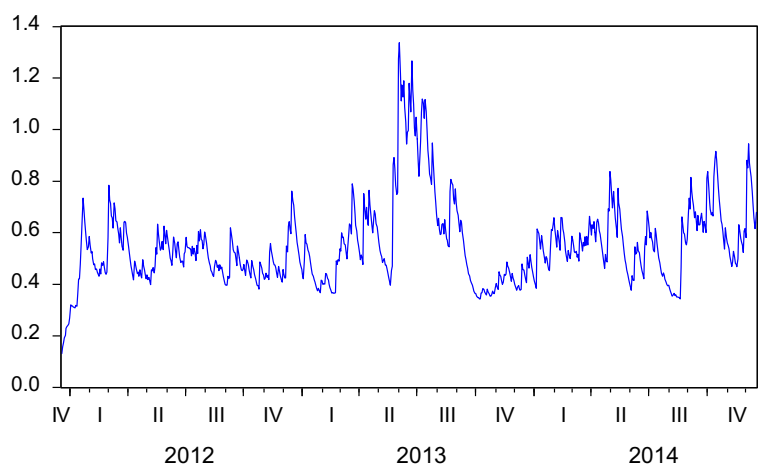

Figure 17. Utilities. 